\title{
Dissemination of information regarding clean technologies in textile processing
}

Received: 17.02.2017; Accepted: 30.05 .2017

See end of the paper for authors' affiliations

\section{MEENU SRIVASTAVA}

Department of Textile and Apparel

Designing, College of Home Science,

Maharana Pratap University of

Agriculture and Technology, UDAIPUR (RAJASTHAN) INDIA
ABSTRACT : The present paper is a part of the research work undertaken by researcher to find out the "Environmental sensitization of textile processing units of Pali district (Raj.)". Findings of the study revealed that majority of the respondents (86.66\%) were not aware about the clean technologies and about eco friendly chemicals and processes. In view of this, the researcher developed an awareness package and organize awareness generating programme at Pali District on "Clean technologies in textile processing units" for generating awareness among textile mill owners. The main aim of this campaign was to sensitize and raise awareness level of textile mill owners about clean technologies.

KEY WORDS: Dissemination, Clean, Technologies, Textile, Processing, Pollution, Environment

- HOW TO CITE THIS PAPER : Srivastava, Meenu and Koka, Vinita (2017). Dissemination of information regarding clean technologies in textile processing. Asian J. Home Sci., 12 (1) : 308-310, DOI: 10.15740/ HAS/AJHS/12.1/308-310. 